\title{
Sustainability-based Life Cycle Analysis of Biomethane as a transportation fuel compared to Diesel and Natural Gas in Arequipa
}

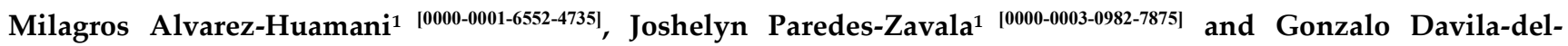 \\ Carpio $^{2 *}$ [0000-0001-7842-9286]
}

\begin{abstract}
${ }^{1}$ School of Environmental Engineering, Universidad Católica de Santa María, Arequipa, Perú; Urb. San José S/N - Umacollo. jparedesz@ucsm.edu.pe; malvarezh@ucsm.edu.pe

${ }^{2}$ School of Pharmaceutical, Biochemistry and Biotechnology Sciences, Universidad Católica de Santa María, Arequipa. Perú; Urb. San José S/N - Umacollo. gdavilad@ucsm.edu.pe

* Correspondence: gdavilad@ucsm.edu.pe
\end{abstract}

\begin{abstract}
The Life Cycle Analysis (LCA) was used to assess the impact of biomethane plant of the "La Católica" in Pedregal-Majes-Arequipa farm, fed with cow manure and holding a production of $60 \mathrm{Nm} 3 /$ day of purified biogas. Life cycle inventory, impact assessment and interpretation were performed. The functional unit established was 1 MJ of energy produced; the study was modeled with SimaPro software, Ecoinvent Database and ReCiPe Midpoint $(\mathrm{H})$ impact assessment methodology, according to the impact categories of climate change and fossil resource depletion. The impact analysis was limited to the Well to Tank (WTT) approach, which involves feedstock transport, substrate mixed, anaerobic digestion, biogas purification, storage and injection of the fuel into transport vehicles. The digestion process generated the highest amount of $\mathrm{CO}_{2}$ emissions (1.79E-02 kg CO $2 \mathrm{eq} / \mathrm{MJ}$-biomethane) and the highest depletion of fossil resources (6.58E-03 kg oil eq/MJ-biomethane), compared to the other fuel production, due to energy consumption and transport infrastructure. Biomethane was then compared to fossil fuels, resulting in natural gas generating the least amount of $\mathrm{CO}_{2}$ emissions, followed by diesel and finally biomethane. For the fossil resource depletion category, biomethane presented the lowest amount of fossil fuel consumption (1.37E$02 \mathrm{~kg}$ oil eq/MJ-biomethane), followed by natural gas and diesel.
\end{abstract}

Key words: Life Cycle Assessment, biomethane, diesel, natural gas, SimaPro, Ecoinvent.

\section{Introduction}

In recent years, the annual emissions of 78 to $80 \%$ of $\mathrm{CO}_{2}$ has been produced by burning fossil fuels around the world, so countries are faced with the responsibility to reduce and control their greenhouse gas emissions, which contribute to climate change [1,2]. Likewise, the growing world population, the demand for energy and the concern about climate change, demand the development of new energy sources. In this framework, biomass stands out for its renewability and availability, with biomethane being increasingly used as a transportation fuel.

Biomethane is produced by the anaerobic digestion of biowaste and can be used for the generation of heat, electricity and as a fuel for the transportation sector. Research conducted in this field in Peru, are diverse and one of them is the one carried out at Fundo La Católica in Majes, as part of the project "Production of biomethane for transportation fuel from biomass waste (Biometrans)", funded by the National Fund for Scientific, Technological Development and Technological Innovation (Fondecyt) and the Catholic 
University of Santa Maria (UCSM), under Agreement No. 111-2017 under the Science and Technology for Development Program (CYTED - project code 918PTE0539). The production and use of this fuel must be justified from an environmental perspective, however, there are few studies where the life cycle impact of this fuel is evaluated compared to others in the transport sector.

In several countries around the world, the Life Cycle Analysis (LCA) tool has started to be used for the identification of environmental impacts along the feedstock extraction, production and use of fuels, especially biomethane [3-7]. In Peru, LCA has been applied in different sectors, as a tool for monitoring environmental impacts in the adaptation or adoption of low-carbon technologies, but these studies are scarce in the transportation and fuels sector, being important to support good decision making, law making, regulations, among others. The present work seeks the application of LCA as a tool for environmental impact assessment throughout the life cycle of biomethane in comparison with non-renewable fuels used in the city of Arequipa.

The results of this study are based on the comparison of the impacts of three fuels through the LCA tool, according to the impact categories of climate change and depletion of fossil resources, for the use of the data in decision making.

\section{Materials and Methods}

For the LCA calculation, the chosen software SimaPro 9.0.0.48, a commercial software tool developed by Pré Consultants for LCA, was used. Likewise, the Ecoinvent database version 3.6 and the ReCiPe Midpoint $(\mathrm{H})$ calculation methodology were used, where the categories of climate change and fossil resource depletion, available at the Technological Center of Catalonia Eurecat, Barcelona, were interpreted.

\subsection{Methodology}

Environmental impacts were calculated using the LCA approach and in accordance with ISO 14040-14044. This involves four phases: definition of the objective and scope, inventory analysis, impact assessment and interpretation $[8,9]$.

\subsection{Objective and scope.}

The objective of the present study was to evaluate the environmental impacts of a renewable fuel such as biomethane obtained from cow manure and compare it with non-renewable fuels such as diesel and natural gas using life cycle analysis as a management tool for decision making and as scopes the systems, the boundaries of each system and the study approach were established, which is equal to defining the fuels and processes to be included in the study. Likewise, $1 \mathrm{MJ}$ of energy produced by the biomethane plant was selected, as a functional unit, for the appropriate subsequent comparison between systems.

\subsection{Life cycle inventory and data acquisition.}

The biomethane Life Cycle inventory (LCI) data were provided by the overall project researchers and by the biogas plant and pressurization laboratory operators; the data were systematized by means of a data collection sheet. The information was obtained in 3 sessions of 3 to 4 hours each, at Fundo La Católica between October and November 2019; data on fuel production, water and electricity consumption, infrastructure dimensions, machinery and 
equipment specifications, as well as emissions to different environmental bodies were requested, which allowed us to analyze the optimal production of biomethane.

The LCI of biomethane was constructed, relating the data collected, the processes and the quantities of biomethane production with the functional unit. All the data were reviewed by the general managers of the Biometrans project for correction, completion, and subsequent validation.

\subsection{Impact Evaluation and Interpretation}

This stage aimed to assess how significant the potential environmental impacts are, making use of data and results from the inventory. The fuel life cycle inventory was analyzed with respect to the chosen impact categories, using the same tools and calculation methodology. Then, the interpretation of the climate change and fossil resource depletion categories was performed and compared with other studies.

\subsection{Comparison between fuels}

Four different scenarios were compared: the first was biomethane produced at the La Católica farm; the second was biomethane fuel from data extracted from the Ecoinvent database; the third was low sulfur diesel extracted from Ecoinvent [10]; and finally, the fourth was natural gas vehicles. For this comparison, the same ReCiPe Midpoint $(\mathrm{H})$ calculation methodology was used, as well as the same impact categories applied previously: climate change and fossil resource depletion. Finally, the results obtained were interpreted by comparing them with the results of other studies.

\section{Results}

The geographical scope of the study was Metropolitan Arequipa, for comparison with other fuels in the same area.

\subsection{System boundaries and functional unit:}

The scenarios considered in this study are as follows:

- Compressed biomethane (BMC) obtained from cow manure,

- Low sulfur diesel (DB5 S50),

- Natural gas for vehicles (NGV).

The limits of the system encompassed the transportation of cattle manure to the plant, biomethane production, storage and filling of the same in a vehicle, i.e., it is considered a study done under the WTT approach as in the studies from different authors [3-5,11]. Likewise, such an approach was applied to diesel and natural gas fuels. The boundaries for the life cycle inventory phase are shown in Figure 1.

The calorific value considered for each fuel is shown in Table 1, data necessary for the subsequent comparison between fuels based on the functional unit, since the units used for the fuels in the software are in $\mathrm{m}^{3}$ (biomethane and natural gas) and $\mathrm{kg}$ (diesel). 


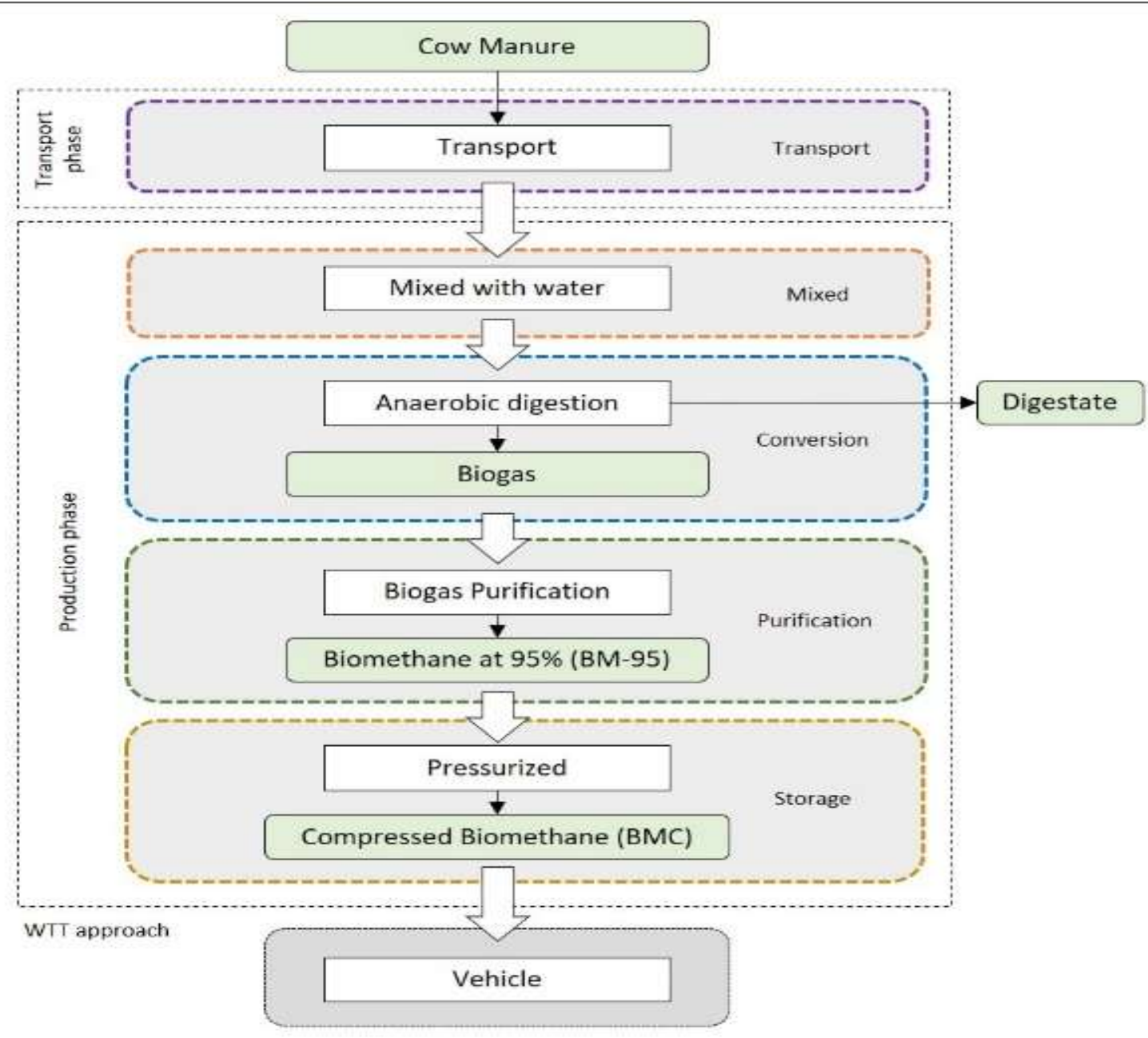

Figure 1. The limits of the Biomethane (BMC) system obtained from cow manure.

Source: own elaboration

Table 1. Heat power of the studied fuels [12]

\begin{tabular}{lcc}
\hline Fuel & Heat-power & Unit \\
\hline Biomethane & 37.5 & $\mathrm{MJ} / \mathrm{m}^{3}$ \\
Diesel & 42.6 & $\mathrm{MJ} / \mathrm{kg}$ \\
Natural Gas & 40.6 & $\mathrm{MJ} / \mathrm{m}^{3}$
\end{tabular}

The limits of the Biomethane (BMC) system obtained from cow manure (Figure 1), are divided in the transport and production stages according to the WTT approach. In the transport stage, the cow manure is moved from the cow barn to the biogas plant, both located within the La Católica farm in Majes, Arequipa. The manure then goes to the production stage, which begins with the process of mixing with water and continues to anaerobic digestion, where biogas and digestate are obtained, the latter being excluded from this study. The biogas then passes to the purification process, where $95 \%$ pure biomethane (BM-95) is produced. Finally, BM-95 is pressurized and stored until it is injected into a transportation vehicle. 
Emissions generated by the short storage time of the manure before transport to the plant are not considered due to uncertainty in the data $[13,14]$.

The DB5 S50 and NG system boundaries (Figure 2) are divided by stages according to the WTT approach. For the DB5 S50 fuel, the extraction stage is considered first, where the crude oil is obtained, this is transported to the production stage where the diesel results, which is finally transported for distribution and injection in a vehicle of the transport sector. As for NG, the extraction, transportation and distribution stages are considered for filling into a vehicle in the transportation sector.

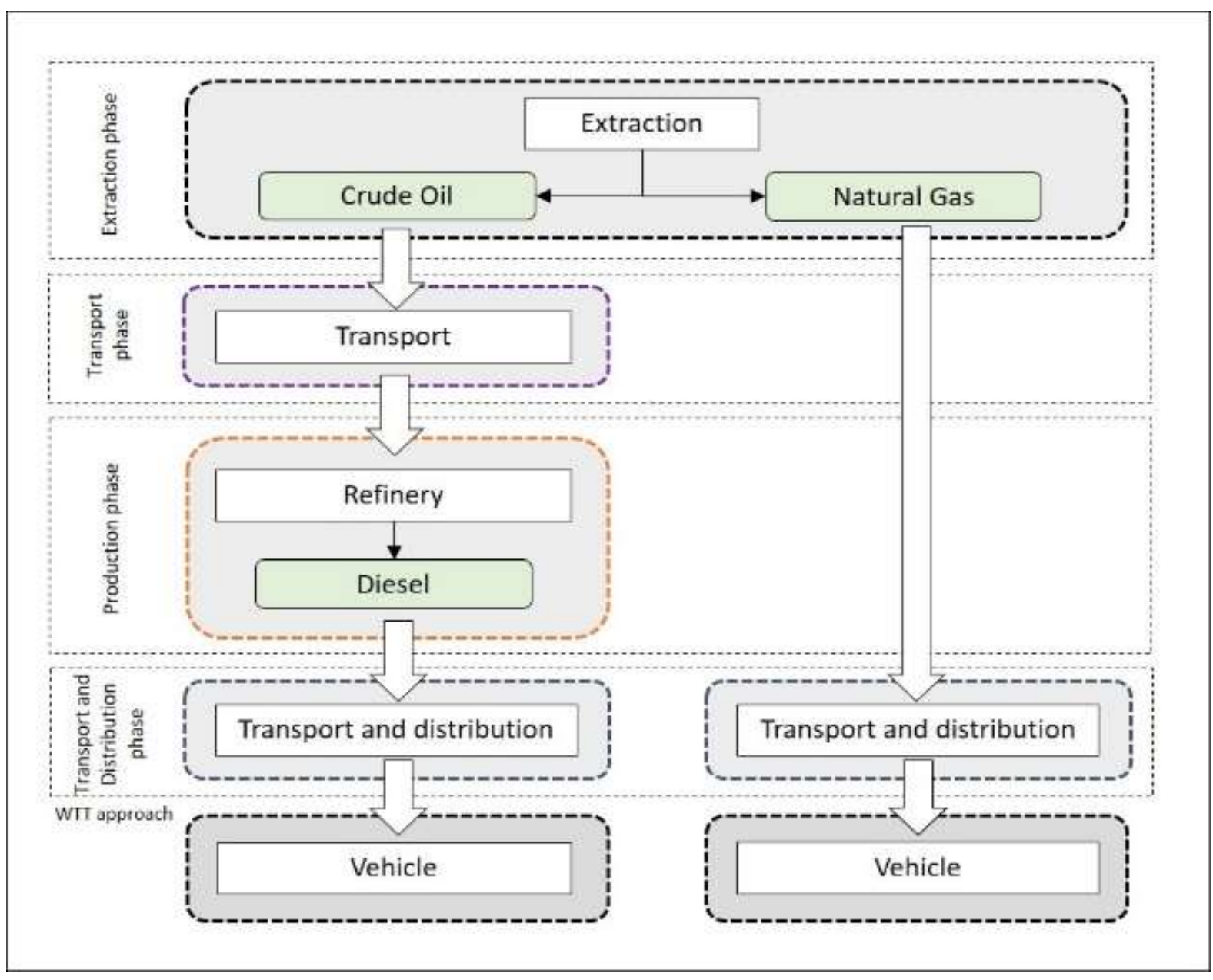

Figure 2. Limits for diesel (DB5 S50) and natural gas (NG) systems. Source: own elaboration

\subsection{Life Cycle inventory and data acquisition}

The data for the biomethane inventory were acquired according to the methodology described in Section 2.3. completing the missing information with data collected through exhaustive bibliographic research. Only the optimal biomethane production at the La Católica farm plant was analyzed, due to the amount of information available.

\subsubsection{Raw material transport stage}


The manure comes from the stabled rearing of 130 cows, unloaded at a rate of $15 \mathrm{~kg}$ per head of cattle. Emissions generated in the short time of its storage before transport to the plant are not considered [13], due to uncertainty in the data and because this feedstock for biomethane production is considered a waste for another activity.

The amount of $180 \mathrm{~kg}$ of manure transported within the La Católica farm along $1 \mathrm{~km}$ distance from the cow barn to the biogas plant was considered. A FIAT 70-66 tractor was used, driven for approximately 30 minutes by one person, with a consumption of 4.55 liters of diesel fuel per week. The transport value considered is equal to the amount of manure transported in one-year times the number of kilometers traveled, which results in $65700 \mathrm{~kg} / \mathrm{km}$.

\subsubsection{Biomethane production stage}

In this stage, the processes of mixing, conversion, biogas purification and storage were considered. The daily, annual and functional unit production quantities of the reference products of each process considered in this study are presented in Table 2. The biomethane production plant has a life expectancy of 25-30 years (represented by 28 years).

The quantities in reference to the functional unit are values representing the amount of manure $(\mathrm{kg})$, water $(\mathrm{kg})$, biogas $\left(\mathrm{m}^{3}\right)$, biomethane $\left(\mathrm{m}^{3}\right)$ and compressed biomethane $\left(\mathrm{m}^{3}\right)$ necessary to produce $1 \mathrm{MJ}$ of energy. For example, if to produce $307968.75 \mathrm{MJ}$ of energy per year $8212.15 \mathrm{Nm}^{3}$ of biomethane were needed, then to produce $1 \mathrm{MJ} 2.67 \mathrm{E}-02 \mathrm{~m}^{3}$ of biomethane were needed.

Table 2. Inventory data of the daily, annual and functional unit reference product input.

\begin{tabular}{|c|c|c|c|c|c|}
\hline $\begin{array}{c}\text { Reference } \\
\text { Product }\end{array}$ & Unit & $\begin{array}{l}\text { Mixing and } \\
\text { Conversion }\end{array}$ & $\begin{array}{c}\text { Biogas } \\
\text { purification }\end{array}$ & Storage & Use \\
\hline \multicolumn{6}{|l|}{ Daily amount } \\
\hline Manure & $\mathrm{kg}$ & 180 & & & \\
\hline Mixing water & $\mathrm{kg}$ & 100 & & & \\
\hline Biogas & $\mathrm{Nm}^{3}$ & & 60 & & \\
\hline BM-95 & $\mathrm{Nm}^{3}$ & & & 57 & \\
\hline BMC & $\mathrm{Nm}^{3}$ & & & & 22.5 \\
\hline Energy & MJ & & & & 843.75 \\
\hline \multicolumn{6}{|c|}{ Annual amount } \\
\hline Manure & $\mathrm{kg}$ & 65700 & & & \\
\hline Mixing water & $\mathrm{kg}$ & 36500 & & & \\
\hline Biogas & $\mathrm{Nm}^{3}$ & & 21900 & & \\
\hline BM-95 & $\mathrm{Nm}^{3}$ & & & 20805 & \\
\hline BMC & $\mathrm{Nm}^{3}$ & & & & 8212.15 \\
\hline Energy & MJ & & & & 307968.75 \\
\hline \multicolumn{6}{|c|}{ Amount in reference to UF } \\
\hline Manure & $\mathrm{kg}$ & $2.13 \mathrm{E}-01$ & & & \\
\hline Wastewater & $\mathrm{kg}$ & 1.19E-01 & & & \\
\hline Biogas & $\mathrm{Nm}^{3}$ & & 7.11E-02 & & \\
\hline BM-95 & $\mathrm{Nm}^{3}$ & & & $6.76 \mathrm{E}-02$ & \\
\hline $\mathrm{BMC}$ & $\mathrm{Nm}^{3}$ & & & & 2.67E-02 \\
\hline Energy (UF) & MJ & & & & 1 \\
\hline
\end{tabular}


The inventory of electrical consumption is shown in Table 3, which lists the machinery included in the study, their respective power, daily and annual operation, annual energy consumption and consumption in reference to the UF.

The consumption in reference to the functional unit represents the electricity consumption of the machinery that was necessary to produce $1 \mathrm{MJ}$ of energy.

Table 3. Machinery used in biomethane production

\begin{tabular}{llllll}
\hline Machinery & $\begin{array}{l}\text { Potency } \\
\mathbf{( k W )}\end{array}$ & $\begin{array}{l}\text { Operati } \\
\text { on } \mathbf{( h / d )}\end{array}$ & $\begin{array}{l}\text { Annual } \\
\text { Operation } \\
\text { (h/year) }\end{array}$ & $\begin{array}{l}\text { Annual } \\
\text { consumption } \\
\mathbf{( k W h )}\end{array}$ & $\begin{array}{l}\text { Consumption } \\
\text { in ref. to UF } \\
\text { (kWh) }\end{array}$ \\
\hline Sludge pump & 0.75 & 4 & 1460 & 1095.00 & $3.56 \mathrm{E}-03$ \\
Compressor 1 & 1.5 & 24 & 8760 & 13140.00 & $4.27 \mathrm{E}-02$ \\
Compressor 2 & 2.24 & 4 & 1460 & 3266.17 & $1.06 \mathrm{E}-02$ \\
Radiator & 0.07 & 4 & 1460 & 102.20 & $3.32 \mathrm{E}-04$ \\
Cooler & 0.02 & 4 & 1460 & 32.12 & $1.04 \mathrm{E}-04$ \\
Water pump & 3.73 & 4 & 1460 & 5443.61 & $1.77 \mathrm{E}-02$ \\
Compressor 3 & 4 & 4.5 & 1642.5 & 6570 & $2.13 \mathrm{E}-02$ \\
\hline
\end{tabular}

\subsubsection{Mixing with water}

In the mixing with water, the dilution of $180 \mathrm{~kg}$ of manure with $100 \mathrm{~kg}$ of water in the feeding pond was considered; the water was residual water from the cleaning of the pig breeding activity developed a few meters from the feeding pond, so it was not necessary to consider its transportation since it was not carried out by means of a vehicle or machinery.

\subsubsection{Digestion}

In the conversion or anaerobic digestion process, two sludge pumps of 0.75 $\mathrm{kW}$ of power and $27 \mathrm{~kg}$ of weight each and a $1.5 \mathrm{~kW}$ and $150 \mathrm{~kg}$ compressor were considered; as infrastructure, the HPTC type biogas plant with double hydrolytic chamber was considered, made up of two containers of $1132.78 \mathrm{~kg}$ estimated weight of iron between both chambers, placed under a concrete base composed of a total of $1803.2 \mathrm{~kg}$ of cement, $3858.4 \mathrm{~kg}$ of sand, $6591.2 \mathrm{~kg}$ of gravel and $873.6 \mathrm{~kg}$ of water. One of the containers houses the two hydrolytic chambers where hydrolysis and acidogenesis are carried out; the other container houses the biodigester, where acetogenesis and methanogenesis are carried out.

As for the equipment, the hydrolytic chambers are made of fiberglass reinforced polyester with a capacity of 2500 liters and a calculated weight of $203.25 \mathrm{~kg}$ between both tanks, which were functional.

Finally, the gas reservoir, made of the same material as the biodigester, has a capacity of $30 \mathrm{~m}^{3}$, resistance of up to 0.2 bar of pressure and a calculated weight of $191.09 \mathrm{~kg}$.

3.2.2.3. Biogas purification 
The machinery included a $2.237 \mathrm{~kW}$ compressor weighing $30.8 \mathrm{~kg}$, a 0.14 $\mathrm{kW}$ radiator weighing $2.26 \mathrm{~kg}$, a $0.022 \mathrm{~kW}$ chiller weighing $46 \mathrm{~kg}$ and a 3.7285 $\mathrm{kW}$ water pump weighing $46 \mathrm{~kg}$.

As for the infrastructure, an iron structure was found to protect the pressurization laboratory with a calculated weight of $894.21 \mathrm{~kg}$, on a concrete base composed of a total of $2318.4 \mathrm{~kg}$ of cement, $4960.8 \mathrm{~kg}$ of sand, $8474.4 \mathrm{~kg}$ of gravel and $1123.2 \mathrm{~kg}$ of water and a galvanized steel roof with a total found weight of $100.5 \mathrm{~kg}$.

Among the equipment considered are the Scrubber filters, where $\mathrm{CO}_{2}$ is removed from the biogas by filtering it with recirculating water $[15,16]$, consisting of two iron towers 3 meters high and 0.29 meters in diameter, with a calculated weight of $221,085 \mathrm{~kg}$. The PSA filters, where water vapor is retained, are composed of two iron towers 2.5 meters high and 0.29 meters in diameter, with a calculated weight of $185,853 \mathrm{~kg}$. A storage tank with a capacity of $1 \mathrm{~m}^{3}$ and a calculated weight of $299,016 \mathrm{~kg}$ was also considered.

\subsubsection{Storage}

In the storage process, a DIDWANIA compressor model SF-5/200 of $4 \mathrm{~kW}$ of power and $568 \mathrm{~kg}$ of weight, which was designed in India and manufactured in China, was considered as machinery. This device is mainly used for compression and filling of natural gas at 200 bar pressures in vehicles, with a filling time of between 3-6 hours. The compressor contains inside it an explosion-proof motor, a control box, a cooling fan, an air and gas separation system, piping, safety components and frame. The gas passes through four stages until it is compressed [17-20].

\subsection{Impact assessment}

The overall results of the life cycle impact assessment of the biomethane plant at the La Católica farm with respect to the 18 impact categories of the assessment method used, ReCiPe midpoint $(\mathrm{H})$, are shown in Figure 3. Likewise, it is shown that transportation of the raw material does not present significant values, this is due to the short distance it travels from the stable to the biogas plant.

Due to the diversity of methodological assumptions in bioenergy LCA studies, specific cases and dependence on regional data such as environmental conditions and policy in each country, direct comparison of the results of a study would be debatable [21]. 
Environmental impact according to impact categories of the biomethane plant in the La Católica farm, Majes, Arequipa.

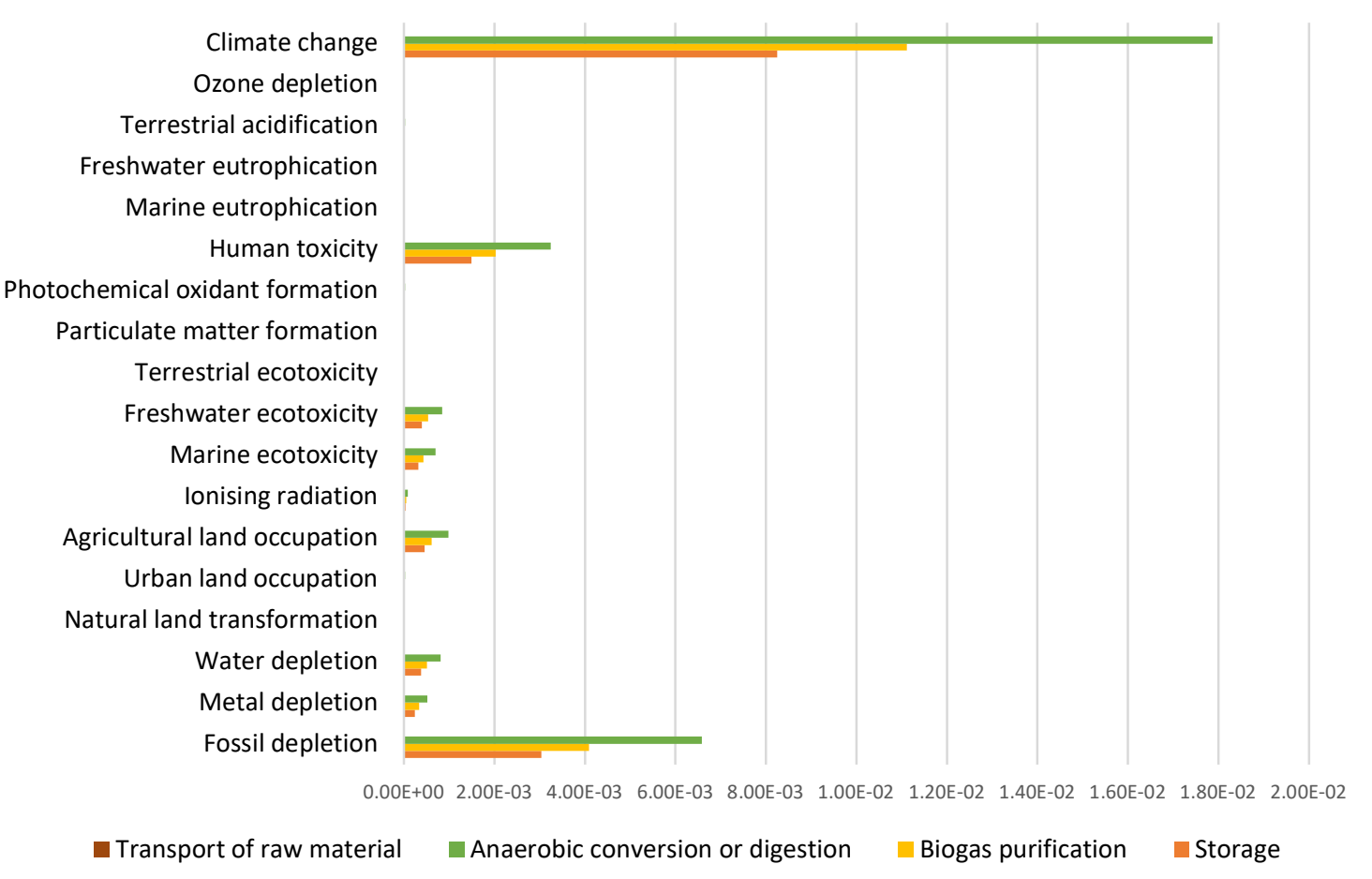

Figure 3. Results of the Life Cycle Analysis of the biomethane plant at La Católica farm, Majes, Arequipa in SimaPro software [22]

In the figure 4, we shown the results of the life cycle assessment according to impact categories of the biomethane plant in the La Católica farm, Majes, Arequipa: Climate change and Depletion of fossil resources.

In the climate change category presented in Figure 4.a, the total $\mathrm{CO}_{2}$ emission of the biomethane plant at the La Católica farm in Majes, Arequipa was 3.72E-02 $\mathrm{kg} \mathrm{CO} 2 \mathrm{eq} / \mathrm{MJ}$-Biomethane produced, which is somewhat related to other studies. As in other studies [3,4,11,23], the conversion or anaerobic digestion process presented the highest amount of $\mathrm{CO}_{2}$ emissions to the atmosphere, $1.79 \mathrm{E}-02 \mathrm{~kg} \mathrm{CO} 2$ eq/MJ-Biomethane; followed by purification, $1.11 \mathrm{E}-02 \mathrm{~kg} \mathrm{CO} 2 \mathrm{eq} / \mathrm{MJ}-$ Biomethane and finally feedstock transport, 5.26E-11 $\mathrm{kg} \mathrm{CO} 2 \mathrm{eq} / \mathrm{MJ}$-Biomethane. The difference is that the other studies did not include the storage process, while we report $8.25 \mathrm{E}-03 \mathrm{~kg} \mathrm{CO}_{2} \mathrm{eq} / \mathrm{MJ}-$ Biomethane.

Regarding the results of the fossil resource depletion category, presented in Figure 4.b, as in the climate change category, there is evidence of a certain relationship between the results obtained in this study with those of other studies such as $[3,4]$, where the conversion process resulted with a higher environmental load or, in this case, is the process in which the largest amount of fossil resources is exhausted, resulting in this study $6.58 \mathrm{E}-03 \mathrm{~kg}$ oil eq/MJBiomethane, followed by fuel purification, $4.09 \mathrm{E}-03 \mathrm{~kg}$ oil eq/MJ-Biomethane and the transportation of feedstock with a not very significant value due to the 
short distance traveled. Again, the difference lies in the fact that other studies did not include storage, while we obtained 3.04E-03 kg oil eq/MJ-Biomethane.

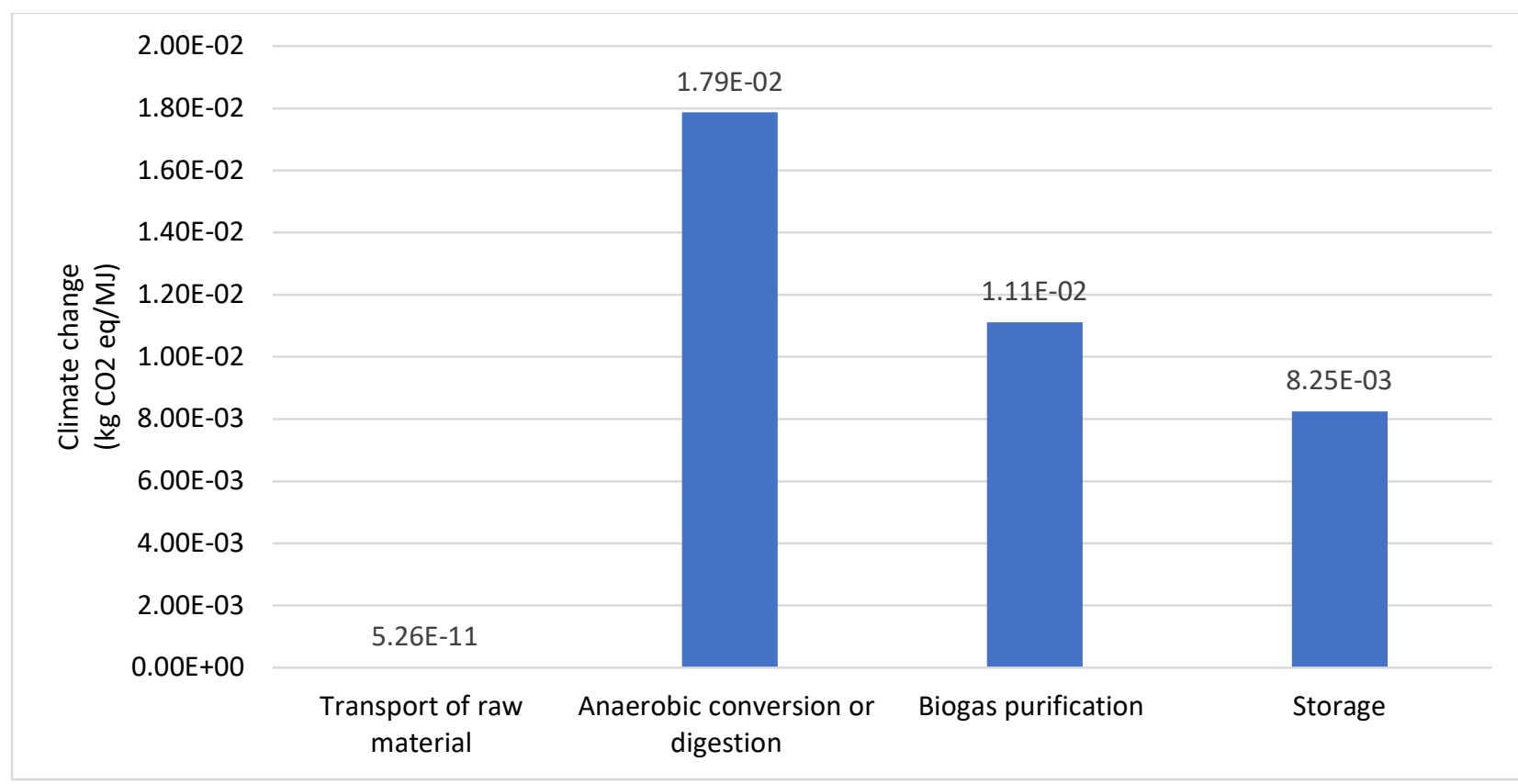

(a)

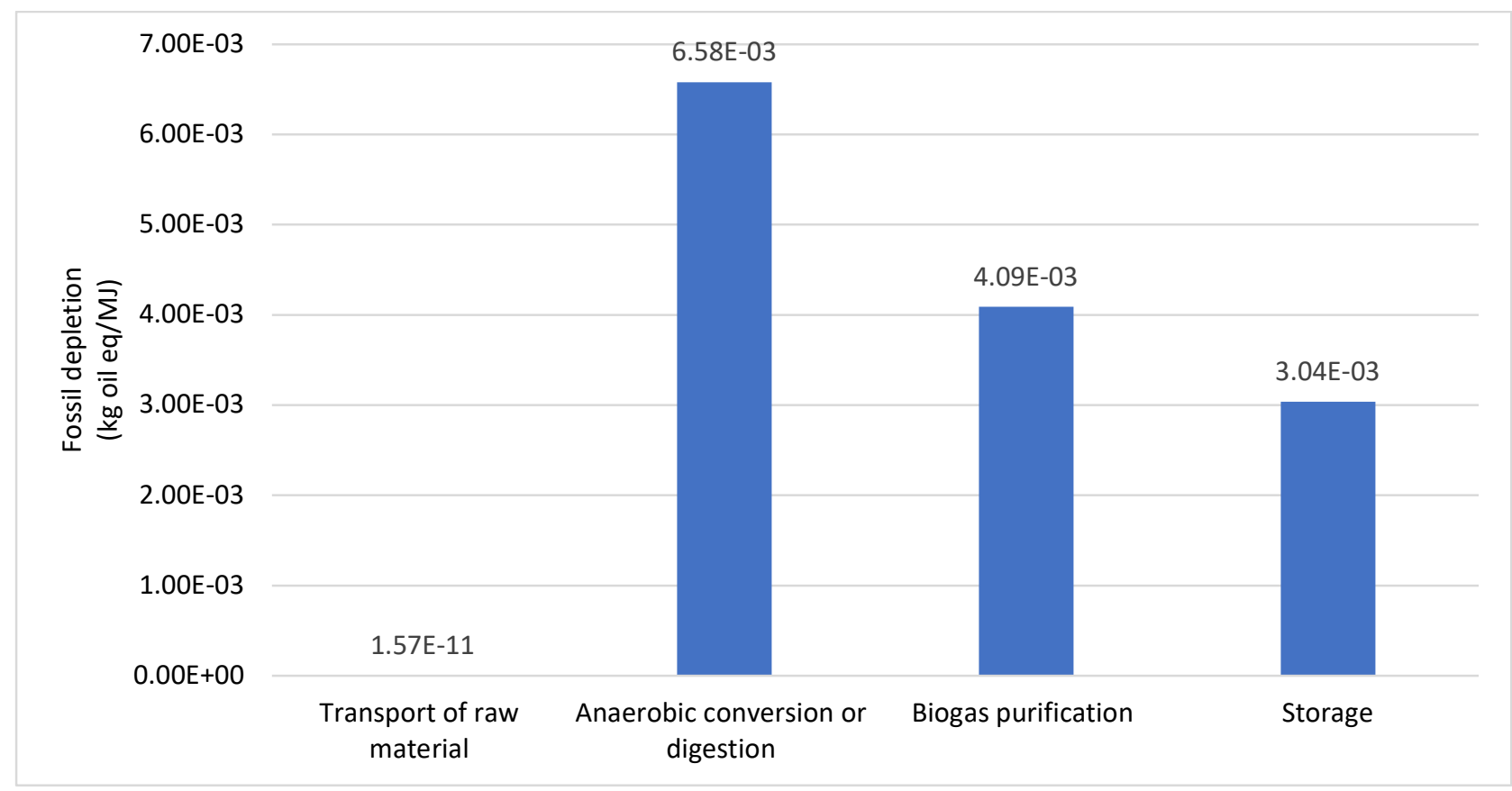

(b)

Figure 4. Results of the life cycle assessment according to impact categories of the biomethane plant in the La Católica farm, Majes, Arequipa: a) Climate change; b) Depletion of fossil resources [22].

3.4. Comparison between fuels

A comparative LCA was carried out to identify the alternative with the lowest environmental impact among the four systems evaluated: biomethane 
produced in the plant, biomethane with data extracted from the Ecoinvent database [10], low sulfur diesel and natural gas for vehicles, also from Ecoinvent. Tables 4, 5 and 6 describe the processes and data used, which were extracted from Ecoinvent for each fuel for the calculation of the comparative life cycle analysis.

Table 4. Ecoinvent database processes for diesel fuels

\begin{tabular}{cc}
\hline Life cycle stage & Ecoinvent processes and data \\
\hline Extraction, & Ecoinvent Process: "Oil \\
transport and & Refinery Operation, ROW" * \\
production & \\
Transport and & Ecoinvent's process: "Diesel, \\
distribution & low sulfur, ROW" * \\
\hline
\end{tabular}

${ }^{*}$ Terminology obtained from Ecoinvent

Table 5. Ecoinvent database processes for natural gas

\begin{tabular}{cc}
\hline Life cycle stage & Ecoinvent processes and data \\
\hline Extraction, & $\begin{array}{c}\text { Ecoinvent process: "Natural } \\
\text { gas, high-pressure, ROW" * } \\
\text { production }\end{array}$ \\
Transport and & Ecoinvent process: "Natural \\
distribution & gas, high pressure, ROW" * \\
& where the emissions from \\
& diesel production are \\
& removed.
\end{tabular}

* Terminology obtained from Ecoinvent

Table 6. Ecoinvent database processes for biomethane

\begin{tabular}{cc}
\hline Life cycle stage & Ecoinvent processes and data \\
\hline $\begin{array}{c}\text { Extraction, } \\
\text { transport and } \\
\text { production }\end{array}$ & $\begin{array}{c}\text { Ecoinvent processes: "Anaerobic } \\
\text { digestion of manure, ROW" *, where the } \\
\text { energy mix was adapted to the Peruvian } \\
\text { context, and "96\% methane by volume of } \\
\text { high-pressure biogas"*. Emissions from } \\
\text { the short storage time of the feedstock } \\
\text { were not included. }\end{array}$ \\
$\begin{array}{c}\text { Ecoinvent process: "Natural gas, high } \\
\text { distribution }\end{array}$ & $\begin{array}{c}\text { pressure, ROW", where emissions from } \\
\text { diesel production are removed. }\end{array}$ \\
\hline
\end{tabular}

* Terminology obtained from Ecoinvent

The results obtained from the comparison of the life cycle impact assessment of biomethane, diesel and natural gas fuels are presented in Figure 5, which shows the 18 main categories of the ReCiPe midpoint $(\mathrm{H})$ impact methodology, of which the ones that show significant values are the climate change category and the depletion of fossil resources. Likewise, in several categories, there is a good environmental performance for natural gas, followed by biomethane produced at the La Católica farm. 
To compare the environmental load trend of fuels, Table 7 and Figure 5 present the results obtained in this study, as well as the comparison with other research on life cycle analysis of biomethane, diesel and natural gas.

In the category of climate change, presented in Figure 6.a, there is evidence of relationship with the results obtained in other studies, as shown in Table 7 and Figure 7 . As in the studies of $[5,13,24]$, the fuel that generated the highest amount of $\mathrm{CO}_{2}$ emissions was biomethane, 5.14E-02 $\mathrm{kg} \mathrm{CO}_{2} \mathrm{eq} / \mathrm{MJ}$-Biomethane from Ecoinvent and 3. 72E-02 $\mathrm{CO}_{2} \mathrm{~kg} \mathrm{CO} 2 \mathrm{eq} / \mathrm{MJ}-$ Biomethane from the La Católica farm, followed by diesel, 2.39E-02 kg CO 2 eq/MJ-diesel, and finally, natural gas, $1.23 \mathrm{E}-02 \mathrm{~kg} \mathrm{CO} 2 \mathrm{eq} / \mathrm{MJ}$-natural gas, which generated the least impact on the category. The difference in data lies in the size of the fuel processing plants that were analyzed in each study, the geographic location and the functional unit.

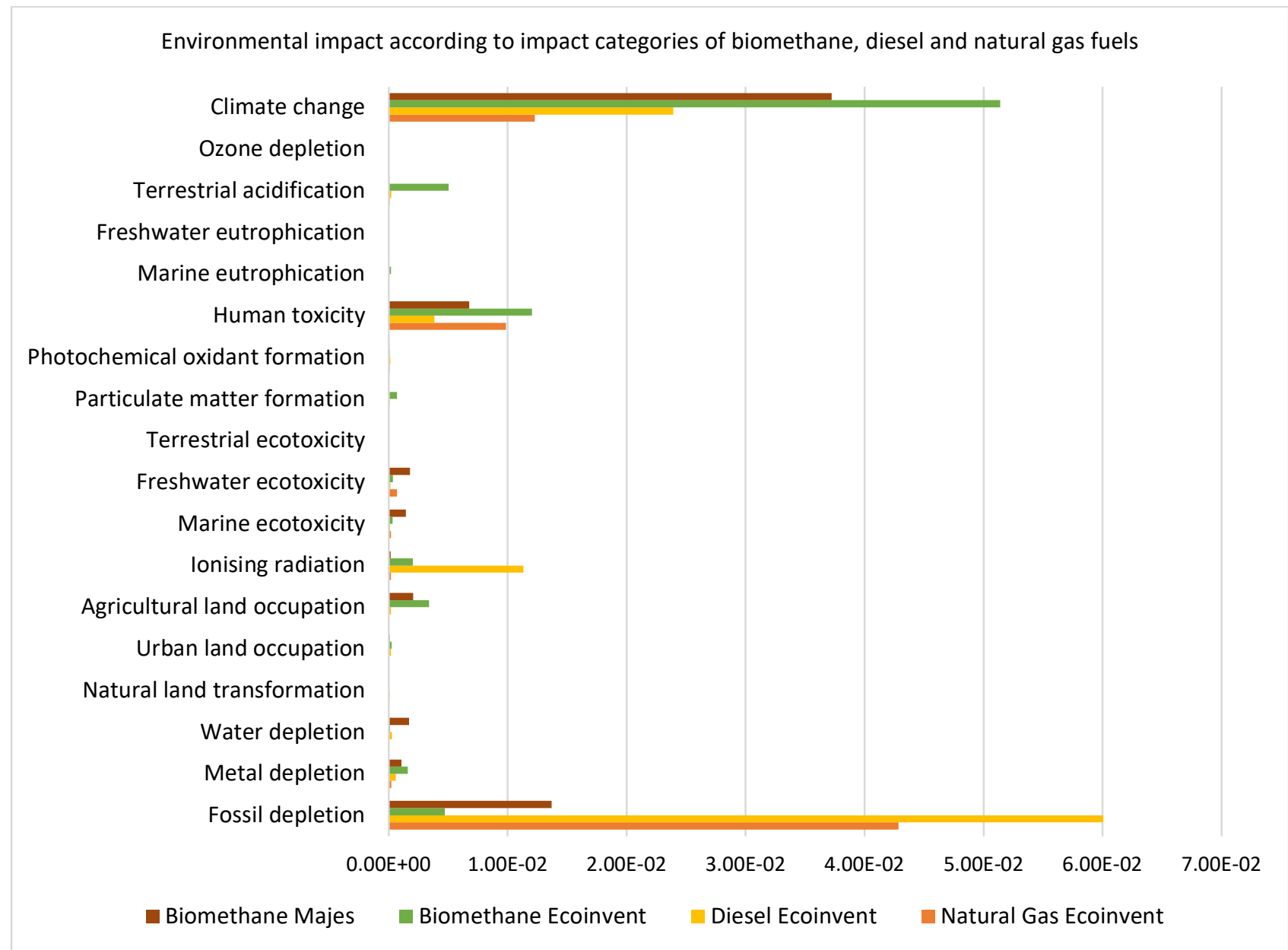

Figure 5. Results of the life cycle assessment comparison of biomethane fuels from La Católica farm, biomethane from Ecoinvent, diesel from Ecoinvent and natural gas from Ecoinvent [22]

Regarding the results of the fossil resource depletion category, presented in Figure 6.b, it correlates with the study of Shanmugam et.al. [25] (Table 7), although this does not consider natural gas, but the fuel that depletes the largest amount of fossil resources is diesel, resulting $6.00 \mathrm{E}-02 \mathrm{~kg}$ oil eq/MJ- 
diesel, followed by natural gas, $4.29 \mathrm{E}-02 \mathrm{~kg}$ oil eq/MJ-natural gas, biomethane from the La Católica farm plant, which resulted in 1.37E-02 kg oil eq/MJBiomethane and finally biomethane from Ecoinvent, $4.72 \mathrm{E}-03 \mathrm{~kg}$ oil eq/MJBiomethane.

Table 7. Comparison of life cycle assessment results for biomethane, diesel and natural gas.

\begin{tabular}{ccccc}
\hline & & \multicolumn{3}{c}{ Fuel } \\
\cline { 3 - 5 } Study & Unit & $\begin{array}{c}\text { Biomet } \\
\text { hane }\end{array}$ & Diesel & Natural gas \\
& & & & \\
\hline Category: Climate change & & & & \\
\hline This study & $\mathrm{kg} \mathrm{CO}_{2}$ eq & $3.72 \mathrm{E}-02$ & $2.39 \mathrm{E}-02$ & $1.23 \mathrm{E}-02$ \\
Collet et ál. (2017) [4] & $\mathrm{kg} \mathrm{CO}_{2}$ eq & $9.00 \mathrm{E}-02$ & - & $5.50 \mathrm{E}-02$ \\
Lyng \& Brekke (2019) [13] & $\mathrm{kg} \mathrm{CO}_{2}$ eq & $3.00 \mathrm{E}-01$ & $2.00 \mathrm{E}-01$ & $3.00 \mathrm{E}-02$ \\
Van Mierlo, Messagie, \& & $\mathrm{kg} \mathrm{CO}_{2}$ eq & $9.80 \mathrm{E}-02$ & $2.50 \mathrm{E}-02$ & $2.0 \mathrm{E}-02$ \\
Rangaraju, (2017) [24] & & & & \\
\hline Category: Depletion of fossil resources & & & \\
\hline \multicolumn{7}{c}{ This study } & $\mathrm{kg}$ oil eq & $1.37 \mathrm{E}-02$ & $6.00 \mathrm{E}-02$ & $4.29 \mathrm{E}-02$ \\
Shanmugam, Tysklind, \& & $\%$ & 8 & 100 & - \\
Upadhyayula, (2018) [25] & & & & \\
\hline
\end{tabular}

$6.00 \mathrm{E}-02$

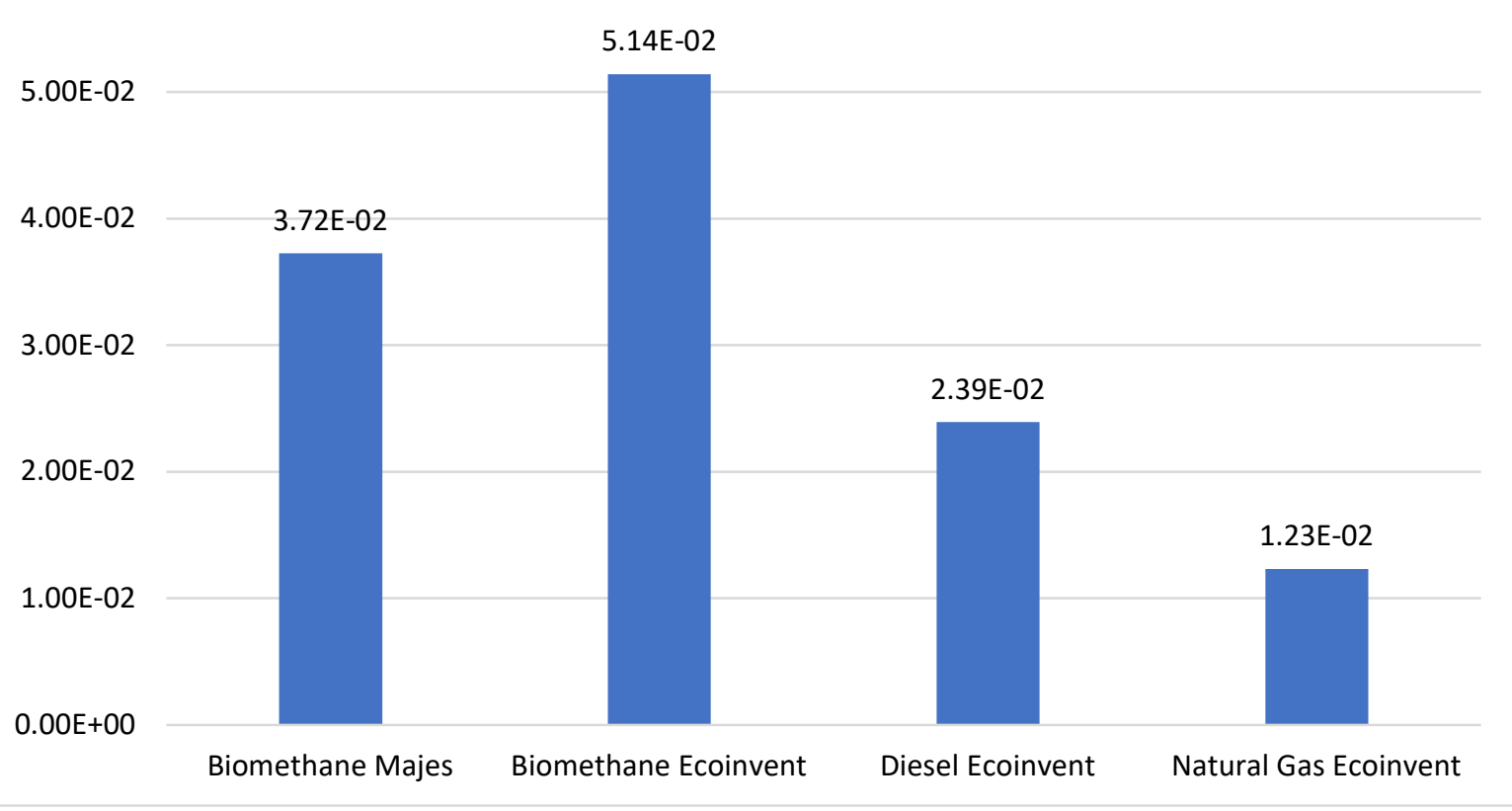

(a) 


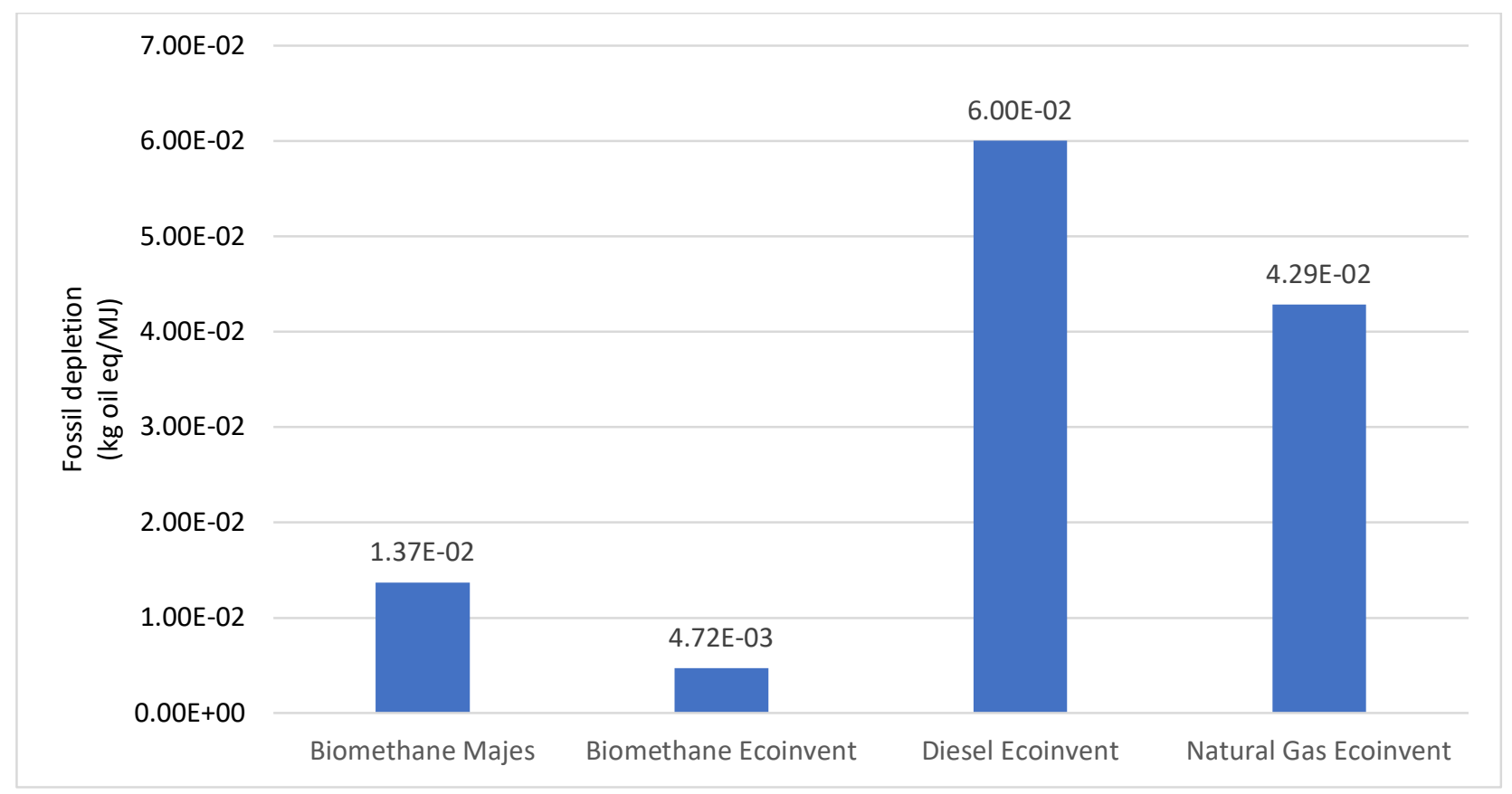

(b)

Figure 6. Results of the comparison of the life cycle impact assessment according to impact categories of the study systems: a) Climate change; b) Depletion of fossil resources [22]

Comparison of life cycle assessment results for biomethane, diesel and natural gas

6.00E-01

$5.00 \mathrm{E}-01$

4.00E-01

3.00E-01

2.00E-01

1.00E-01

$0.00 \mathrm{E}+00$

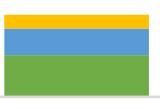

This study

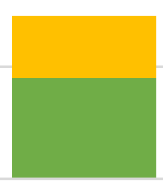

Collet et ál. (2017)

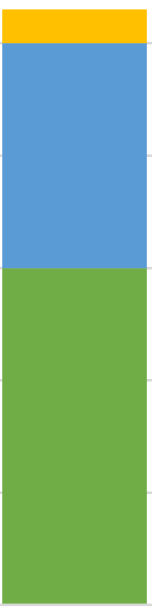

Lyng \& Brekke (2019)

Biomethane $\square$ Diesel $\square$ Natural gas

Figure 7. Comparison of life cycle assessment results for biomethane, diesel and natural gas with respect to the climate change category $[5,13,24]$ 


\section{Discussion}

Considering that the principal objective of the present study was to evaluate the environmental impacts of a renewable fuel such as biomethane obtained from cow manure and compare it with non-renewable fuels such as diesel and natural gas using life cycle analysis as a management tool for decision, the research was oriented in this direction.

In relation to system boundaries and functional unit, the selected functional unit was also used in other investigations that had biomethane as a study system $[5,11,21]$, as well as other fuels.

In the raw material transport stage, the emissions generated in the short time of its storage before transport to the plant were not considered [19], due to uncertainty in the data and because this feedstock for biomethane production is considered a waste for another activity.

About impact assessment, related to climate change category, it is known that in the conversion or anaerobic digestion process, biogas is generated and digestate biol as a by-product. In this study, biogas is considered to be the only product generated in this process, and digestate is excluded because it does not participate in the biomethane production process and because of the uncertainty of the information available. Therefore, none of the impacts of the conversion process were assigned to the digestate [19], thus increasing the environmental burden to biogas in the conversion process in all categories.

However, if the digestate were used as fertilizer in the agricultural activities of the La Católica farm and there were records of such activity, the impacts of the conversion process could be assigned to both products, biogas and digestate, instead of just one; this could be a good practice recommendation. Within this framework, the study by Koido et al. [11] considers and takes advantage of this digestate for the fertilization of local fig crops, additionally generating economic benefits.

In biomethane production, it was identified that electric energy consumption tends to be a major source of GHG as in the studies $[5,11,25]$. Even, in the study by Shanmugam [25] it is highlighted that, replacing the use of diesel with biomethane in both the transportation and power sectors in the diesel production processes, may not have any significant environmental benefit if it is that the electricity used in the biomethane processes comes from carbon-intensive grid mixes or non-renewable sources. In this case, the biomethane plant located in Majes is supplied by energy from the Siguas hydroelectric power plant, through the company SEAL - Sociedad Eléctrica del Sur Oeste S.A., according to the Plan de Desarrollo Local Concertado 2016-2021 (Gobierno Regional de Arequipa, 2016) [26].

In the last national inventory conducted on greenhouse gases in 2014, hydropower is included as a renewable energy resource and is not considered a source of GHG emissions due to its low contribution. On the other hand, in the IPCC report on renewable energy sources, a value between 4 and $14 \mathrm{~g} \mathrm{CO}_{2}$ $\mathrm{eq} / \mathrm{kWh}$ is estimated, since all artificial or natural freshwater systems can emit GHG due to the organic matter that decomposes $[27,28]$. In this sense, the high environmental load is explained in the conversion and purification processes, 
which is where a greater amount of machinery is used and, therefore, where there is a greater contribution of electric energy consumption.

In relation to fossil resource depletion category, we identified that the greatest fuel depletion in the conversion process was due to the large infrastructure used in this process and the weight of its materials, which meant an expense of fossil fuels in transportation for its mobilization to the La Católica farm, especially the metal containers and the hydrolysis tanks, which are the heaviest infrastructure and equipment, respectively [29]. In this framework, according to [30,31], who worked analyzing a biomethane plant, the plant infrastructure tends to contribute to the full life cycle impacts.

Also, the study focused on a WWT approach rather than a well-to-wheel approach, due to little data available, and the current possibility of biomethane application as a fuel in a vehicle in the transportation sector. Additionally, some data were bibliographically supported or averaged due to lack of real data in the plant: the annual production of compressed biomethane, the electrical consumption of the radiator and cooler machinery, the weight of the materials composing the metal containers, the hydrolysis tank, the geomembrane biodigester, the gas reservoir, the iron structure, the scrubber and PSA filters and the storage tank.

\section{Comparison between fuels:}

The results show a good environmental performance for natural gas compared to the other fuels studied, even better than biomethane. According to According to [5], this could be explained because biomethane is not recovered or injected into the gas network when the plant is not in operation, it is generally burned to reduce direct methane emissions, thus generating higher $\mathrm{CO}_{2}$ emissions for biomethane fuel than for the continuous process that natural gas and diesel have.

This is mainly due to two important aspects: production level and infrastructure. In the case of biomethane from the La Católica farm, production is limited for the level of infrastructure it has, so this represents a greater environmental burden for the plant in the quantities of fuel produced. According to [11], the most sensitive parameter is the plant's production level which, especially for biomethane, must be kept high for a viable operation. Moreover, as demonstrated by [30] the plant infrastructure tends to contribute to the full life cycle impacts of the fuel under study. On the other hand, as for natural gas and even diesel, the amount of production and the size of the infrastructure destined for their extraction and production processes are of large industrial dimensions, in which the environmental load is distributed.

If the size of the biogas plant increases, as well as its production, becoming an industrial plant that supplies a large population, as diesel and natural gas currently do [32,33], then, like the aforementioned fossil fuels, the environmental load would tend to be distributed in the plant $[11,30,34]$.

It was identified that, as in the study of Shanmugam [33], fossil fuels generate greater depletion of them, since these are required for both extraction, transportation of raw material and production (operation of machinery). Whereas, for biomethane, fossil resources are depleted only in the transportation of raw material, but there is no depletion in its use because it is a renewable fuel. Likewise, the biomethane produced at the La Católica farm has a greater depletion of fossil resources than the biomethane extracted from the Ecoinvent database because the level of production in the former is much 
lower, thus placing a greater environmental burden on this fuel than in the latter.

\section{Conclusions}

It is concluded that natural gas generated the least amount of $\mathrm{CO}_{2}$ emissions, followed by diesel and the biomethane produced at the La Católica farm, due to the level of production, the infrastructure of the processing plant, the distance to transport and the leaks.

Likewise, biomethane consumed the least amount of fossil resources, followed by natural gas and diesel.

Although the production and use of industrial biomethane in any sector in the country represents a good opportunity, it must be justified from an environmental perspective, as was done in this study, because biomethane involves additional energy consumption and emissions with respect to other fuels already established, like the natural gas and diesel. In this case, biomethane must be produced in large scale in Arequipa to generate the least amount of $\mathrm{CO} 2$ emissions and reduce its environmental impact.

Author Contributions: Conceptualization, M.A. and G.D.; methodology, M.A. and G.D.; software, M.A.; validation, M.A., G.D. and J.P.; formal analysis, M.A. and J.P.; investigation, M.A.; resources, M.A.; writing-original draft preparation, M.A. and G.D.; writing - review and editing, G.D. and J.P.; supervision, J.P. and G.D.; project administration, M.A. and G.D.; funding acquisition, M.A. and G.D. All authors have read and agreed to the published version of the manuscript.

\section{Funding}

This research was supported by the by the National Fund for Scientific, Technological Development and Technological Innovation (Fondecyt) and the Catholic University of Santa Maria (UCSM), under Agreement No. 111-2017 under the Science and Technology for Development Program (CYTED - project code 918PTE0539).

\section{Acknowledgments}

To the officials of the Fundo La Católica in Majes and the researchers who developed of the project "Production of biomethane for transportation fuel from biomass waste (Biometrans)".

To EURECAT technology center of Cataluña, Spain, for their support and training in the use of the SimaPro software and the LCA methodology.

Institutional Review Board Statement: Not applicable.

Informed Consent Statement: Not applicable.

Data Availability Statement: Data sharing not applicable.

Conflicts of Interest: The authors declare no conflict of interest

\section{References}

1. Khondaker, A. N., Hasan, M. A., Rahman, S. M., Malik, K., Shafiullah, M., \& Muhyedeen, M. A. (2016). Greenhouse gas emissions from energy sector in the United Arab Emirates - An overview. Renewable and Sustainable Energy Reviews, 59, 1317-1325. doi:10.1016/j.rser.2016.01.027.

2. Beil, M., \& Beyrich, W. (2013). Biogas upgrading to biomethane. In A. Wellinger, J. Murphy, \& D. Baxter (Eds.), The Biogas Handbook. Science, Production and Applications. Woodhead Publishing Series in Energy (pp. 342-377). doi:10.1533/9780857097415.3.342. 
3. Florio, C., Fiorentino, G., Corcelli, F., Ulgiati, S., Dumontet, S., Güsewell, J., \& Eltrop, L. (2019). A Life Cycle Assessment of Biomethane Production from Waste Feedstock Through Different Upgrading Technologies. Energies, 12(718).

4. Ardolino, F., \& Arena, U. (2019). Biowaste-to-Biomethane: An LCA study on biogas and syngas roads. Waste Management, 87, 441-453. doi:https://doi.org/10.1016/j.wasman.2019.02.030.

5. Collet, P., Flottes, E., Favre, A., Raynal, L., Pierre, H., Capela, S., \& Peregrina, C. (2017). Technoeconomic and Life Cycle Assessment of methane production via biogas upgrading and power to gas technology. Applied Energy, 192, 282-295. doi:https://doi.org/10.1016/j.apenergy.2016.08.181.

6. Budzianowski, W. M., \& Brodacka, M. (2017). Biomethane storage: Evaluation of technologies, end uses, business models, and sustainability. Energy Conversion and Management, 141, 254-273. doi:https://doi.org/10.1016/j.enconman.2016.08.071.

7. Mokhatab, S., Poe, W. A., \& Mak, J. Y. (2019). Natural Gas Fundamentals. In Handbook of Natural Gas Transmission and Processing (Fourth Edition). Principles and Practices (pp. 1-35). doi:10.1016/B978-0-12815817-3.00001-0

8. ISO 14040:2006. (2006a). International Organization for Standarization (ISO) 14040:2006, Environmental Management - Life cycle assessment - Principles and framework.

9. ISO 14044:2006. (2006b). International Organization for Standarization (ISO) 14044:2006, Environmental Management - Life cycle assessment - Requirements and guidelines.

10. Ecoinvent. (2019). Ecoinvent Database Version 3.6 . Retrieved from www.ecoinvent.org.

11. Koido, K., Takeuchi, H., \& Hasegawa, T. (2018). Life cycle environmental and economic analysis of regional-scale food-waste biogas production with digestate nutrient management for fig fertilisation. Journal of Cleaner Production, 190, 552-562. doi:https://doi.org/10.1016/j.jclepro.2018.04.165

12. Engineering ToolBox. (2020, enero 17). Fuels-Higher and Lower Calorific. Retrieved from The Engineeting ToolBox: https://bit.ly/2wzvck4

13. Lyng, K.-A., \& Brekke, A. (2019). Environmental Life Cycle Assessment of Biogas as a Fuel for Transport Compared with Alternative Fuels. Energies, 12(3), 532 doi: https://doi.org/10.3390/en12030532

14. Sharma, A., \& Strezov, V. (2017). Life cycle environmental and economic impact assessment of alternative transport fuels and power-train technologies. Energy, 133, 1132-1141. doi:https://doi.org/10.1016/j.energy.2017.04.160

15. Peña, G., \& Dávila, G. (2017a). Eliminación de vapor de Agua por sistema de filtrado PSA, para la producción de Biometano. Seminario Internacional: Procesamiento de Residuos Orgánicos Agrícolas, 1, 9-15.

16. Peña, G., \& Dávila, G. (2017b). Evaluación de 3 presiones y 3 temperaturas en sistema de filtrado por depuración (Scrubber) de CO2 para la producción de Biometano. Seminario Internacional: Procesamiento de Residuos Orgánicos Agrícolas, 1, 51-56.

17. Peña, G. (2017a). Convenio $N^{\circ}$ 111-2017: Producción de biometano para combustible de transporte a partir de residuos de biomasa. Arequipa: Universidad Católica de Santa María.

18. Peña, G. (2017b). Proyetos en temas estratégicos: Memoria tecnica del Proyecto "Producción de biometano para combustible de transporte a partir de residuos de biomasa". Arequipa: Universidad Católica de Santa María.

19. Peña, G., Reátegui, J., Cárdenas, L., Castro, J., Mejía, F., Mestas, S., \& Roque, F. (2018a). Manual de producción y uso de biometano presurizado a baja y alta presión. (F. Roque, Ed.) Arequipa: Universidad Católica de Santa María.

20. Peña, G., Reátegui, J., Cárdenas, L., Castro, J., Mejía, F., Mestas, S., \& Roque, F. (2018b). Norma Técnica de Empresa (NTE) Norma técnica producción y almacenamiento de biometano presurizado. Arequipa: Universidad Católica de Santa María.

21. Ferreira, S. F., Buller, L. S., Berni, M., \& Forster-Carneiro, T. (2019). Environmental impact assessment of end-uses of biomethane. Journal of Cleaner Production, 230, 613-621. doi:https://doi.org/10.1016/j.jclepro.2019.05.034.

22. SimaPro. (2020). SimaPro 9.0.0.49. Retrieved from https://simapro.com/

23. Ravina, M., \& Genon, G. (2015). Global and local emissions of a biogas plant considering the production of biomethane as an alternative end-use solution. Journal of Cleaner Production, 102, 115-126. doi:10.1016/j.jclepro.2015.04.056

24. Van Mierlo, J., Messagie, M., \& Rangaraju, S. (2017). Comparative environmental assessment of alternative fueled vehicles using a life cycle assessment. Transportation Research Procedia, 25, 3435-3445. doi:https://doi.org/10.1016/j.trpro.2017.05.244.

25. Shanmugam, K., Tysklind, M., \& Upadhyayula, V. K. (2018). Use of Liquefied Biomethane (LBM) as a Vehicle Fuel for Road Freight Transportation: A Case Study Evaluating Environmental Performance of Using LBM for Operation of Tractor Trailers. Procedia CIRP, 69, 517-522. doi:https://doi.org/10.1016/j.procir.2017.11.133. 
26. Gobierno Regional de Arequipa. (2016). Plan de desarrollo local concertado 2016-2021: Mapa de redes de generación. Arequipa. Retrieved from https://bit.ly/33sXTNq

27. Gielen, D., Boshell, F., Saygin, D., Bazilian, M. D., Wagner, N., \& Gorini, R. (2019). The role of renewable energy in the global energy transformation. Energy Strategy Reviews, 24, 38-50. doi:10.1016/j.esr.2019.01.006.

28. IPCC. (2011). Fuentes de energía renovables y mitigación del cambio climático. Retrieved from https://bit.ly/2PsigCp

29. Quispe, J. (2019). Evaluación de los impactos socioeconómicos del uso de biogás presurizado producido en el biodigestor de alta eficiencia de la UCSM, en la irrigación el Pedregal Majes - Arequipa [Tesis de maestría, Universidad Católica de Santa María]. Repositorio UCSM. Retrieved from https://bit.ly/34TmsID

30. Mezzullo, W. G., McManus, M. C., \& Hammond, G. P. (2013). Life cycle assessment of a small-scale anaerobic digestion plant from cattle waste. Applied Energy, 102, 657-664. doi:https://doi.org/10.1016/j.apenergy.2012.08.008

31. Vázquez-Rowe, I., Kahhat, R., Larrea-Gallegos, G., \& Ziegler-Rodriguez, K. (2019). Peru's road to climate action: Are we on the right path? The role of life cycle methods to improve Peruvian national contributions. Science of The Total Environment, 659, 249-266. doi:10.1016/j.scitotenv.2018.12.322

32. Osinergmin. (2014). La industria del gas natural en el Perú. A diez años del Proyecto Camisea. In J. Tamayo, J. Salvador, A. Vásquez, \& R. García (Eds.). Lima. Retrieved from https://bit.ly/3fzq4NX

33. Osinergmin. (2015). La industria de los hidrocarburos líquidos en el Perú: 20 años de aporte al desarrollo del país. In J. Tamayo, J. Salvador, A. Vásquez, \& R. De la Cruz (Eds.). Lima - Perú. Retrieved from https://bit.ly/3egbj2e.

34. Unrean, P., Lai Fui, B. C., Rianawati, E., \& Acda, M. (2018). Comparative techno-economic assessment and environmental impacts of rice husk-to-fuel conversion technologies. Energy, 151, 581-593. doi:10.1016/j.energy.2018.03.112 